\title{
THE EFFECT OF ZINC SUPPLEMENTATION ON PERFORMANCE OF GROWING LAMBS
}

\author{
M.M. Farghaly; S.M. Mousa; G.A. Abd El-Hafez and M.A. Abd El-Rahman \\ Animal Production Department, Faculty of Agriculture, Assiut University, Egypt.
}

\section{SUMMARY}

$\mathrm{T}$ his study was investigated to determine the effect of zinc source either from organic or inorganic on lambs performance, blood metabolites and carcass characteristics. Fifteen local lambs (about six months old and an average body weight of $26.5 \pm 3.1 \mathrm{~kg}$ ) were divided into three similar groups (5 lambs each). The control group (G1) was fed the basal diet consisting of wheat straw and concentrates mixture. While, the other two tested groups were fed the same basal diet, supplemented with $20 \mathrm{mg} \mathrm{Zn} / \mathrm{head} /$ day as Zinc Sulphate (G2) and $20 \mathrm{mg} \mathrm{Zn/head/day} \mathrm{as} \mathrm{Zinc} \mathrm{methionine}$ (G3). All animals of these groups were fed $60 \%$ of their requirements as concentrate mixture and the rest of other requirements were covered from wheat straw, which was given ad libitum. The experiment was extended for 6 month. The results indicated that the average daily gain (ADG) was higher $(P<0.05)$ in zinc sulphate and zinc methionine groups than in control group (130 and $132 \mathrm{gm} / \mathrm{day}$ vs. $99 \mathrm{gm} / \mathrm{day}$, respectively). There were no significant differences among groups in total feed intake. Feed conversion ratio as dry matter intake/ $g$ gain was improved in zinc methionine and zinc sulphate groups when compared with control one. However, the differences among groups were not significant. Supplementation of $\mathrm{Zn}$-meth increased $(\mathrm{P}<0.05)$ the level of zinc in serum as compared with control and zinc sulphate groups. Also, serum cholesterol was higher $(\mathrm{p}<0.05)$ in Zn treated groups than in control one. While, serum concentration of total protein, Albumin, globulin, glucose, triglycerides and total antioxidant capacity (TAC), were not affected by zinc supplementation. Zn supplementation in a form of organic or inorganic had no effect on dressing percentage and carcass cuts in lambs. In conclusion zinc supplementation in form of inorganic or organic may improve lambs performance.

Keywords: growing lambs, Zn-methionine, Zn sulphate, performance, blood metabolites, carcass cuts.

\section{INTRODUCTION}

Zinc is one of the important microelements which have effect on growth, reproduction and immune system by influencing enzyme activity of animals and gene expression (Chesters, 1997). Zinc is needed for the functions of over 100 enzymes and essential for DNA, RNA and absorbed amino acids, which involved protein synthesis and cell division in growing lambs and calves (McDowell, 1995). Also, zinc improves hoof quality (Kessler et al. 2003). The deficiency of $\mathrm{Zn}$ in ruminant diets includes reduce of feed intake, growth rate and feed efficiency (McDowell et al., 1993). Previous research has shown that a severe $\mathrm{Zn}$ deficiency can result in impaired growth and altered immune function in lambs (Droke and Spears 1993), and calves (Brummerstedt et al. 1971) and reduced wool growth of sheep (White et al., 1994). Traditionally, the major sources of $\mathrm{Zn}$ amongst the mineral supplements for animal feeding were inorganic salts like $\mathrm{Zn}$ sulphate $\left(\mathrm{ZnSO}_{4}\right), \mathrm{Zn}$ oxide $(\mathrm{ZnO}), \mathrm{Zn}$ chloride $\left(\mathrm{ZnCl}_{2}\right)$, etc. However, recent studies showed that $\mathrm{Zn}$ supplementation through mineral proteinases or mineral amino acid chelates as organic sources had higher retention (Lardy et al., 1992), more bioavailability (Spears, 1989) and higher tissue concentrations (Cao et al., 2000) compared to inorganic sources. Hempe and Cousins (1989) reported that $\mathrm{Zn}$-methionine complex is transported intact from the intestinal lumen into mucosal cells, increasing tissue supply of $\mathrm{Zn}$ and thereby improving animal productivity.

Supplementation of $\mathrm{Zn}$ methionine to a diet containing more than $25 \mathrm{mg} \mathrm{Zn} / \mathrm{kg}$ DM did not affect feed intake in ewes (Salama et al., 2003), goats (Puchala et al., 1999), growing lambs (Droke et al., 1998) and beef steers (Malcolm-Calliset al., 2000). Brethour, (1984) reported that supplement organic $\mathrm{Zn}$ improve growth performance and carcass characteristics of feedlot cattle. Spears (1989) concluded that the performance of heifers did not differ $(\mathrm{P}>.10)$ between that fed $\mathrm{ZnO}$ and those receiving $\mathrm{Zn}$ Meth, however more improvement was noticed for the Zn-Meth treatment. Spears (1989) and Hill et al. (1987) found no differences in Zn bioavailability between organic and inorganic sources when they 


\section{Farghaly et al.}

measure plasma $\mathrm{Zn}$ or plasma alkaline phosphatase as indices of $\mathrm{Zn}$ bioavailability. The aim of study is to examine the effect of zinc from organic and inorganic source on performance and carcass characteristic in growing lambs.

\section{MATERIALS AND METHODS}

\section{Animals, rations and management:}

The experiment was carried out at the experimental farm of Animal Production Department, Faculty of Agriculture, Assuit University, Egypt. Fifteen healthy local males (six month's old and $26.5 \pm 3.1 \mathrm{~kg}$ weigh) were divided into three groups (five males each), according to their average live body weight. The average initial weights were similar in all groups. Lambs were kept in individual pens. Group one was served as control diets (G1) and was fed the basal diet consisting of wheat straw and concentrates mixture. While the other treated groups were fed the same basal diet, but supplemented with either $20 \mathrm{mg} \mathrm{Zn} / \mathrm{head} /$ day of Zn sulphate (Zn-So4, G2) or $20 \mathrm{mg} \mathrm{Zn} / \mathrm{head} / \mathrm{day}$ as Zinc methionine (Zn-Met, G3). The doses of $\mathrm{Zn}$ were added to the diets as dietary supplement. The source of zinc-methionine is Sulfozyme Agro Pvt. Ltd., India.

The animal's requirements for CP and TDN were calculated according to NRC (1985). The animals were randomly allotted to experimental diets. All animals of these groups were fed $60 \%$ of their requirements as concentrate mixture and the rest of other requirements were covered from wheat straw, which was given ad libitum, the quantity of concentrated mixture were adjusted every two weeks according to changes in body weight (NRC,1985). Fresh water were available free of choice. Rations were offered once daily at 8.00 a.m. and the feed orts were weighed daily through the experimental period and actual feed intake was calculated. Feed conversion ratio was calculated and expressed in terms of gm dry matter (DM), total digestible nutrients (TDN) and starch value (SV) per gm body weight gain. Animals were fed individually in locally manufactured mangers. The experimental period lasted for 195 days and consisted of two periods, i.e. 15 adjustment period followed by 6 months experimental period. Animals were weighed in two days every other week before morning feeding. Body weight was averaged to the nearest $0.1 \mathrm{~kg}$. The ingredients of concentrate mixture were corn (47\%), wheat bran (20\%), soybean meal (30\%), limestone (2\%) and salt $(1 \%)$. The proximate analysis of concentrated mixture and wheat straw were clear in table (1).

\section{Blood Sampling:}

Blood samples were monthly taken from all animals at interval for determination serum total protein, albumin, globulin, cholesterol, triglyceride, zinc and total antioxidant capacity. Globulin was obtained by differences between serum total protein and albumin.

\section{Slaughtering:}

At the end of the experiment three animals of each group were slaughtered. Fasting body weight was record before slaughter. Immediately after slaughtering weight of head, pelt, liver, lungs, heart, spleen, kidneys, kidney fat, caul fat, sex organs and heart fat were recorded. Dressing percentage to fasting body weight was calculated. The carcass was splatted according to Brown and Williams (1979). Weights of tail, leg, loin, rack breast, 1-6 ribs, and 7-12 ribs were recorded too. The longissimus muscle piece was taken for proximate analysis to determine moisture, fat, crude protein and ash according to AOAC (2000).

\section{Statistical analysis:}

Statistical analysis was carried out using general linear model (G.L.M) of S.A.S (2001) program, version 8.2. Differences between groups in performance, blood metabolites and carcass characteristics were evaluated by one way ANOVA. The significance differences between treatment means were tested by Duncan Multiple Range Test (Steel and Torrie, 1980). The data were presented in mean \pm S.E.M. Level of significance was set at $\mathrm{P}<0.05$. Statistical model as follow:

$$
Y_{i j}=\mu+T_{i}+E_{i j}
$$

Where: $Y_{i j}=$ the observation $i j, \mu=$ the overall mean, $T_{i}=$ the effect due to treatment $i ., E_{i j}=$ the experimental error. 


\section{RESULTS AND DISCUSSION}

\section{Body weight and average daily gain:}

The average body weight gain (BWG) was not affected by $\mathrm{Zn}$ supplementation (Table 2). However, the average daily gain (ADG) of Zn-So4 and Zn-Met groups were higher $(\mathrm{P}>0.05)$ than control one. Inclusion of Zinc sulphat and Zinc-Methionine as a dietary supplement to diets improved average daily gain of lambs by about 25 and $24 \%$ as compared with control group, respectively. Similar results were found by Garg et al. (2008) and Puchala et al. (1999). In addition, Spears and Kegley (2002) found no differences in performance of steers fed supplement with zinc oxide and zinc proteinate, but the ADG tended to be higher in steers fed zinc proteinate.

\section{Feed intake:}

The total DM intake was not affected by the source of zinc. However, the group fed Zn-Meth improved $(\mathrm{P}<0.05)$ total intake in terms of TDN, SV and DCP intake as compared with control group. Our results were agreement with previous results reported on lambs (Nagalakshmi and Himabindu, 2013), lactating cows (Wang et al., 2013), feedlot steers (Caldera, 2012) and buffalo calves (Hassan et al., 2016). The increase of TDN, SV and DCP intake with supplement of inorganic and organic Zn to the diet of lambs may be attributed to improve in nutrient digestibility (Garg et al., 2008). However, Malcolm-Callis et al. (2000) found negative effect with Zn supplementation on DMI. Such effect may be due to higher intake of $\mathrm{Zn}$ decreased diet palatability. Dietary levels of $\mathrm{Zn}$ in the current experiment were within normal ranges and would not affect diet palatability (NRC, 1985).

\section{Feed conversion ratio:}

Regarding feed conversion ratio expressed as g DMI, TDN and SV /g gain for lambs fed Zn-Meth, Zn-So4 and control diet were shown in table (2). Although no significant differences were observed among groups, however, numerical differences were found among groups. Lambs fed Zn-Meth and Zn-So4 recorded lower DM, TDN and SV unit/unit of gain than lambs fed control diet. The lowest DCP required for each gain unit was observed in lambs fed control group. The improvement of fed conversion in groups fed $\mathrm{Zn}-\mathrm{Meth}$ and $\mathrm{Zn}-\mathrm{So} 4$ may be attributed to higher daily gain of these groups or due to improve feeding value for such diets in terms of TDN and SV. The results in our study agreement with those of Nagalakshmi and Himabindu (2013), they found that ether dose or source of $\mathrm{Zn}$ had no significant effect on weight gains, nutrient intake and feed efficiency of lambs. Fadayifar et al. (2012) showed that supplementation of $20 \mathrm{mg} \mathrm{Zn/kg} \mathrm{DM} \mathrm{to} \mathrm{the} \mathrm{basal} \mathrm{diet} \mathrm{improved} \mathrm{performance}$ (average daily gain and feed efficiency) of lambs. Similar observations were found in calves (Wright and Spears, 2004 and Mandal et al., 2007) and steers (Spears et al., 1991).

\section{Concentrations of blood metabolites:}

The data in Table (3) revealed that there were no significant differences $(\mathrm{P}>0.05)$ in serum total protein, albumin, globulin, glucose, triglycerides and total antioxidant capacity (TAC) of lambs due to Zn-supplemented diet. However, the average value of serum cholesterol concentration of lambs fed diets supplemented with $\mathrm{Zn}-\mathrm{SO} 4$ or $\mathrm{Zn}-$ Meth were higher $(\mathrm{P}>0.05)$ than that of lambs fed control diet. The higher value of cholesterol may be attributed to the increase of thyroid gland activity as a result of $\mathrm{Zn}$ supplementation. Liu et al. (2001) reported that $\mathrm{Zn}$ is essential for proper thyroid function and participates in synthesis and action of thyrotropin-releasing hormone (TRH). Similar results were observed by Hassan et al. (2016) who reported that Zn-methionine and Zn-sulphate had a positive effect on total $\mathrm{T}_{3}$ which was significantly elevated due to $\mathrm{Zn}$ supplements to buffaloes claves ration. Similar result observed in lambs by Berrie et al. (1995), they found that addition of Zn- Meth to feed of lambs increased serum growth hormone, prolactin, and triiodothyronine as compared with inorganic Zn or control groups. Nazifi et al. (2002) found significant positive correlations between serum thyroxin and cholesterol and triglyceride levels in clinically healthy male camels. however, others studies showed no significant correlation between serum thyroid hormones and cholesterol levels in camels, male goats and fat tailed sheep (Nazifi et al., 2007 and Mansourian, 2010).

Results of the present work showed that level of serum $\mathrm{Zn}$ was increased $(\mathrm{P}<0.05)$ in $\mathrm{Zn}$-Meth group as compared with $\mathrm{Zn}-\mathrm{So} 4$ and control groups. Our result suggests that adding $20 \mathrm{mg} / \mathrm{head} / \mathrm{day}$ from organic source to growing lambs' diet containing $22 \mathrm{mg} \mathrm{Zn/kg} \mathrm{DM}$ will increase serum $\mathrm{Zn}$ concentration. Similar to our findings, previous evidence demonstrated that supplementation of $\mathrm{Zn}$ could increase the plasma Zn concentration in male goats (Salama et al., 2003) and finishing lambs (Fadayifar et al., 2012). Spears et al. (1989) attributed the higher value of plasma Zn with Zn-Meth 


\section{Farghaly et al.}

supplementation due to slower release of $\mathrm{Zn}$ from the $\mathrm{Zn}$-Meth and this increase $\mathrm{Zn}$ absorption, besides facilitating $\mathrm{Zn}$ transport across the intestinal mucosa. Garg et al. (2008), also suggested that the bioavailability of was higher as compared to ZnSO4. Similarly, Hassan et al, (2016) found that the level of serum $\mathrm{Zn}$ of buffaloes calves was increased $(\mathrm{P}<0.05)$ in Zn-meth group as compared with $\mathrm{Zn}$ SO4 or control groups. Also, calves fed diet supplemented with $\mathrm{Zn}$-sulphate was higher $(\mathrm{P}<0.05)$ for serum $\mathrm{Zn}$ concentration than control group.

\section{The effect of zinc source on Carcass characteristics:}

Results presented in table $(4)$ showed that there are no significant $(\mathrm{P}<0.05)$ differences between control group and groups fed different sources of zinc in hot carcass, dressing percentage, internal organs and carcass components except the weight of head, the pelt weight and hot carcass, which these are significantly $(\mathrm{P}<0.05)$ higher in group fed $\mathrm{Zn}$-Meth than $\mathrm{Zn}-\mathrm{SO} 4$ and control groups. Also, the right and left sides weights tended to be higher in lambs fed different sources of zinc as compared with control group. Results indicated that the hot carcass was affected by the slaughter weight. These results are conformed by Cameron and Drury $(1985)$ who found a highly significant $(\mathrm{P}<0.01)$ effect of slaughter weight on hot carcass in lambs. Haryanto et al. (1994) reported that slaughter weight, carcass yield, carcass percentage and carcass linear measurement did not differ between control and zinc methionine treatment. Similarly, Berrie et al. (1995) found no differences on cold or hot carcass weight, dressing percentage, kidney, pelvic, and heart fat for lambs groups received either zinc methionine or Zn-So4. Nagalakshmi and Himabindu (2013) found that the dose and source of Zn had no effect on the pre slaughter weight, hot carcass weight, dressing percentage and edible and nonedible proportion of carcass. Greene et al. (1988) reported that zinc oxide did not affect carcass traits, but $\mathrm{Zn}$ methionine increased fat thickness, percentage of kidney, pelvic and heart fat, and quality grade compared to control and $\mathrm{ZnO}$-supplemented steers.

Table (5) showed that the rack breast weights of lambs fed Zn-Meth is higher by about 32 and 23 $\%$ than control and $\mathrm{Zn}-\mathrm{So} 4$, respectively. Also, the tail weight was increased by about $40 \%$ in $\mathrm{Zn}$ Meth and $48 \%$ in Zn-So4 as compared with control group, respectively. Such improvement of carcass components may be due to the increase of both daily gain and body weight of lambs fed zinc. Gravet and Rosenhahn (1965) found a positive correlation between daily gain and the percentages of muscular tissues and fat. Nagalakshmi and Himabindu (2013) found that the meat yield was higher and fat yield was lower in $\mathrm{ZnSO}_{4}$ fed lambs compared to $\mathrm{Zn}$ proteinate.

The chemical analysis of longissimus muscle in table (6) show that the supplement different sours of zinc not significantly effected on longissimus muscle composition. However, a numerical difference is found in fat composition of longissimus muscle. Lambs received Zn-Meth as dietary supplement decrease fat content in longissimus muscle by about 43 and $65 \%$ when compared with control and Zn-So4, respectively. This finding with lambs differs from previous data that suggested Zn-Met supplementation increased marbling in beef cattle (Greene et al., 1988 and Spears and Kegley, 2002), but agrees with the results of other studies (Martin et al., 1987 and Stobart et al., 1987). Greene et al. (1988) attributed the improving in marbling score with supplement $\mathrm{Zn}$-Meth due to increase supply of methionine to the small intestine for absorption. Field et al. (1985) attributed the rule of $\mathrm{Zn}$ for decrease carcass fat due to alter lipid metabolism or it could be indirect through hormones such as luteinizing hormone, follicle stimulating hormone and testosterone which are influenced by level of $\mathrm{Zn}$ in the diet (Lei et al. 1976). Also, the effect of $\mathrm{Zn}$ oxide could also be indirect through its effect on rumen microbial activity and subsequent volatile fatty acid production (Ott et al. I966).

\section{CONCLUSION}

From the present study it could be concluded that supplementation of $20 \mathrm{mg} \mathrm{Zn} / \mathrm{head} / \mathrm{day}$ either $\mathrm{Zn}$ Meth or Zn-SO4 to basal ration of lambs contain about $40 \mathrm{mg} / \mathrm{Zn} / \mathrm{kg}$ DM improved daily and feed conversion ratio of growing lambs. The addition of Zn-Meth to diets of lambs increased serum zinc. Also, serum cholesterol was increase in $\mathrm{Zn}$ supplement groups. The dressing percentage and carcass characteristics not affected with supplement zinc. 


\section{REFERENCES}

AOAC, Association of Official Analytical Chemists (2000). Official Methods of Analysis, 16th ed.: AOAC. AOAC, Gaithersburg, MD, USA.

Berrie, R. A. O. M. Hallford, and M. L. Galyean, (1995): Effects of Zinc Source and Level on Performance, Carcass Characteristics, and Metabolic Hormone Concentrations of Growing and Finishing Lambs. The professional Animal Scientist $11: 149-156$.

Brown, A.J. and D.R. Williams (1979). Sheep carcass evaluation-measurements of comition using a standardized butchery method. Meat Reasrch Institute, Bristol, KK, Memo. No. 38.

Brummerstedt, E., T. Flagstad, A. Basse, and E. Andresen. 1971. The effect of zinc on calves with hereditary thymus hypoplasia (lethal trait A46). Acta. Pathol. Microbial. Scand. Sect. A 79:686.-687.

Caldera, E. (2012) Effect of zinc concentration and source on performance and carcass characteristics of feedlot steers, Colorado State University. Libraries.

Cameron, N.D. and D.J. Drury (1985). Comparison of terminal sire breed for growth and carcass traits in crossbred lambs. Anim. Prod. 40: 315.

Cao, J., P. R. Henry, R. Guo, R. A. Holwerda, J. P. Troth, R.C. Littell, R. D. Miles and C. B. Ammerman (2000). Chemical characteristics and relative bioavailability of supplemental organic zinc sources for poultry and ruminants. J. Anim. Sci., 78: 2039-2054.

Chesters, J. K. 1997. Zinc. In: B. L. O’Dell, and R. A. Sunde (ed.) Handbook of Nutritionally Essential Mineral Elements. pp 185-230. Marcel Dekker Inc., New York.

Droke, E.A., Gengelbach, G.P.and Spears, J.W. (1998). Influence of level and source (inorganic vs organic) of zinc supplementation on immune function in growing lambs. Asian Australian Journal of Animal Science, 11:139-144.

Droke, E. A., and J. W. Spears. 1993. In vitro and in vivo immunological measurements in growing lambs fed diets deficient, marginal or adequate in zinc. J. Nutr. Immunol. 2:71.-90

Fadayifar, A., Aliarabi, H., Tabatabaei, M. M., Zamani, P., Bahari, A., Malecki, M., Dezfoulian, A. H. (2012) Improvement in lamb performance on barley based diet supplemented with zinc. Livestock Science 144:285-289.

Field, R. A., Bennett, G. L., Munday, R. (1985) Effect of excess zinc and iron on lamb carcass characteristics. New Zealand Journal of Agricultural Research 28:349-355.

Garg, A. K., Mudgal, V. and Dass, R. S. (2008) Effect of organic zinc supplementation on growth, nutrient utilization and mineral profile in lambs. Animal Feed Science and Technology 144:8296.

Greene, L. w., D. L. Lunt, F. M. Byers, N. K. Chirase, C. E. Richmond, R. E. Knutson, and G. T. Schelling. 1988. Performance and carcass quality of steers supplemented with zinc oxide or $\mathrm{Zn}$ Met. J. Anim. Sci. 66:1818.

Haryanto, B., 1. Maha, D. Supriatna, B.W. Setiadi, A. Djajanegra and A. Sukmawati, 1994. Carcass yield of sheep fed zinc methionine and less degradable protein supplemented ration. Sustainable animal production and the environment. Proceedings of the 7th AAAP Animal Science Congress, Bali, Indonesia, 11-16 July, 2: 543-544.

Hassan, E. H.; M.M. Farghaly and G.M. Solouma (2016): Effect of zinc supplementation from inorganic and organic sources on nutrient digestibility, some blood metabolites and growth performance of growing buffalo calves. Egyptian J. Nutrition and Feeds, 19 (1) : 1-10.

Hempe, J. M., and R.J. Cousins (1989). Effect of EDTA and Zinc Methionine complex on zinc absorption by rat intestine. J. Nutr. 119: 1179-1187.

Hill, D. A., E. R. Peo and A. J. Lewis. 1987. Effect of zinc source and picolinic acid on 65Zn uptake in an in vitro continuous-flow perfusion system for pig and poultry intestinal segments. J. Nutr. 117:1704.

Kessler, J., Morel, I., Dufey, F.A., Gutzwiller, A., Stern, A.and Geyes, H.(2003). Effect of organic zinc sources on performance, zinc status, and carcass, meat, and claw quality in fattening bulls. Livestock Product Science, 81:171-1171. 


\section{Farghaly et al.}

Lardy, G., M.S. Kerley, and J.A. Patterson (1992). Retention of metal proteinates by lambs. J. Anim. Sci. 70 (Suppl.1): 314.

Lei, K. Y.; Abbasi, A.; Prasad, A. S. 1976: Function of pituitary-gonadal axis in zinc deficient rats. American journal of physiology 6: 1730-1732.

Liu, N., L. Pingsheng, X. Qing Z. Li, Z. Zhiying, W. Zhengzhou, L. Yanfen, F. Wejing and Z. Lianzhen, 2001. Elements in erythrocytes of population. Trace Element Res., 84: 37-43.

Malcolm-Callis, K. J., G. C. Duff, S. A. Gunter, E. B. Kegley, and D. A. Vermeire. 2000. Effects of supplemental zinc concentration and source on performance, carcass characteristics, and serum values in finishing beef steers. J. Anim. Sci. 78:2801-2808.

Mandal, G. P., Dass, R. S., Isore, D., Garg, A. K. and Ram, G. (2007) Effect of zinc supplementation from two sources on growth, nutrient utilization and immune response in male crossbred cattle (Bos indicus $\times$ Bos taurus) bulls. Animal Feed Science and Technology 138:112.

Mansourian AR (2010). The state of serum lipids profiles in sub clinical hypothyroidism: A review of the literature. Pak J Biol Sci; 13: 556-5.

Martin, J., c. A. Strasia, D. R. Gill, R. H. Hicks, K. Ridenour, G. Dolezal, and F. N. Owens. 1987. Effect of $\mathrm{Zn}$ Met on live performance and carcass merit of feedlot steers. J. Anim. Sci. 65(Suppi. 1):500 (Abs.).

McDowell, L.R, J.H. Conrad and F.G. Hembry, 1993. Mineral for Grazing Ruminants in Tropical Regions. pp: 42.

McDowell, L.R.(1995). Minerals in Animal and Human Nutrition. Academic Press, NewYork, NY, USA, p. 272.

Nagalakshmi, D., Parashuramulu, S., Srinivasa, D., Rao and Vikram,1. (2013).Effect of inorganic and various organic sources of zinc and their combinations on in vitro gas production and in vitro digestibilities. International Journal of Pharmacy and Biological Sciences,3:462-466.

Nazifi, S., M. Saeb and S. M. Ghavami, 2002. Serum lipid profile in Iraninan fat-tailed sheep in late pregnancy, at parturition and during the post-parturition period. J. Vet. Med. A, 49: 9-12.

Nazifi S, Saeb M, Rowghani E (2007). Studies on the physiological relationship between thyroid hormones, serum lipid profile and erythrocyte antioxidant enzymes in clinically healthy Iranian fat-tailed sheep. Bulg J Vet Med 2007; 10(3): 161-167.

NRC. (1985). "Nutrient Requirements of Sheep". (6 $6^{\text {th }}$ Ed.) National Academy of Sciences, National Research Council, Washington, DC.

Ott, E. A.; Smith, W., H.; Harrington, R. B.; Stob, M.; Parker, H. E.; Beeson, W. M. 1966: Zinc toxicity in ruminants. II. Physiological changes in tissues and alterations in rumen metabolism in lambs.Journal of animal science 25: 424-431.

Puchala, R., T. Sahlu and J.J. Davis, 1999. Effect of zinc methionine on performance of Angora goats. Small Ruminant Res., 33: 1-8.

S.A.S (2001). SAS/ STAT Guide for personal computer (version 8.1 End). SAS. INST., Cary, N.C.

Salama AAK, Caja G, Albanell E, Such X, Caslas R, Plaixats.2003. Effects of dietary supplements of zinc-methionine on milk production, udder health and zinc metabolism in dairy goats. J Dairy Res; 70: 9-17.

Spears, J. W., Schlegel P., Seal, M. and Lloyd, K. E. (2004) Bioavailability of zinc from zinc sulfate and different organic zinc sources and their effects on ruminal volatile fatty acid proportions. Livestock Production Science 90:211-217.

Spears, J. W. (1989) Zinc methionine for ruminants: relative bioavailability of zinc in lambs and effects of growth and performance of growing heifers. Journal of animal science 67:835-843.

Spears, J. W. and Kegley, E. B. (2002) Effect of zinc source (zinc oxide vs zinc proteinate) and level on performance, carcass characteristics, and immune response of growing and finishing steers. Journal of animal science 80:2747-2752.

Spears, J.W., Harvey, R.W. and Brown Jr., T.T. (1991). Effects of zinc methionine and zinc oxide on performance, blood characteristics, and antibody titer response to viral vaccination in stressed feeder calves. Journal of American Veterinary Medicine Association,199:1731-1733.

Steel, R.G. and J.H. Torrie (1980). "Principles and Procedures of Statistics". A Biometrical Approach (2 nd Ed) Mc Grow- Hill Book Co., New York. 
Stobart, R. H., D. Medeiros, M. Riley, and W. C. Russell. 1987. Effects of Zn Met supplementation on feedlot performance, carcass characteristics and serum profiles of lambs. J. Anim. Sci. 65(Suppl. 1):500 (Abs.).

Suttle, N.F.(2010). Mineral Nutrition of Livestock, 4th ed. CAB International, Oxford, UK.

Wang, R. L., Liang, J. G., Lu, L., Zhang, L.Y., Li, S. F. and Luo, X. G. (2013) Effect of zinc source on performance, zinc status, immune response, and rumen fermentation of lactating cows. Biological trace element research 152:16-24.

White, C.L., Martin, G.B., Hynd, P.I. and Chapman, R.E. (1994). The effect of zinc deficiency on wool growth and skin and wool follicle histology of male Merino lambs. British Journal of Nutrition, 71:425-435.

Wright, C.L. and Spears, J.W. (2004). Effect of zinc source and dietary level on zinc metabolism in Holstein calves. Journal of Dairy Science, 87:1085-1091. 
تأثير اضافه الزنك على أداء الحملان النامية

محسن محمد فرغلى ، سليمان مصيلحى موسى ، جلال عبد المطلب عبد الحافظ و محمد اسعد عبد الرحمن

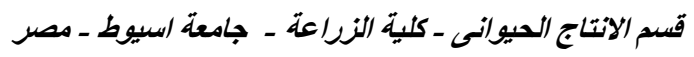

أجريت هذة الدراسه لبحث تأثير أضافة الزنكا إما من مصادر عضوية أو غير عضوية وطريقة الأعطاء على أداء الحيوانات

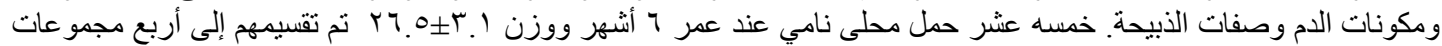

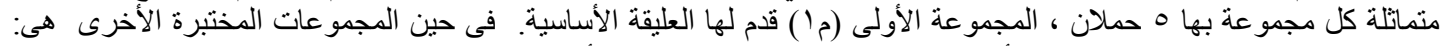

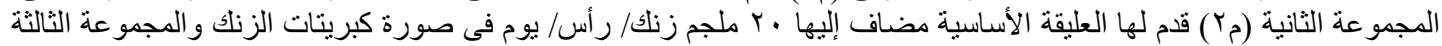

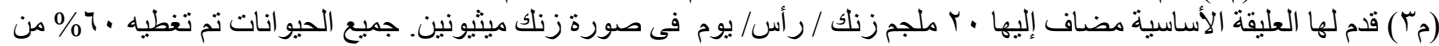

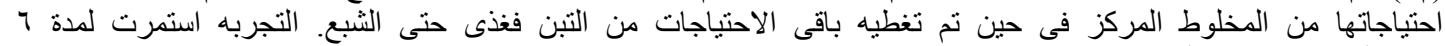

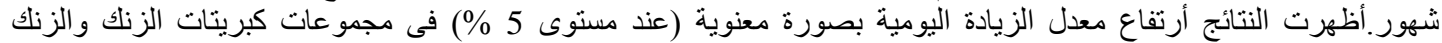

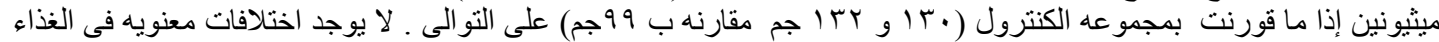

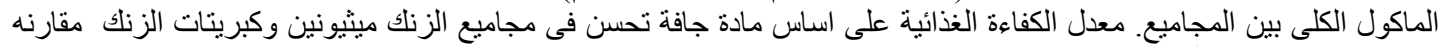

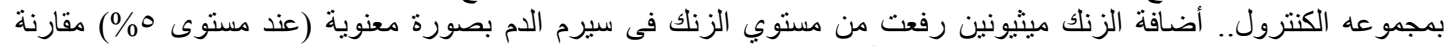

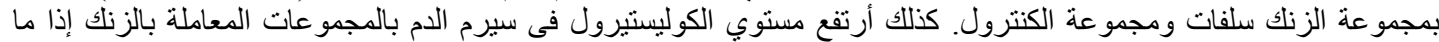

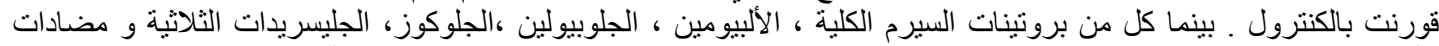

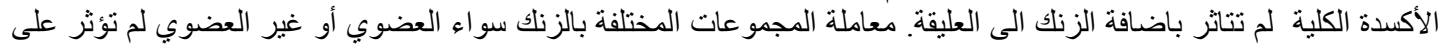

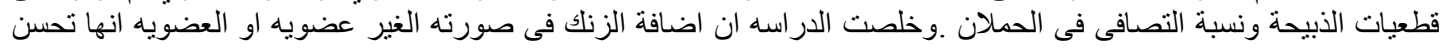
من اداء الحملان النامية . 
Table (1): Chemical composition of concentrate mixture and wheat straw

\begin{tabular}{lcc}
\hline Item & $\begin{array}{c}\text { Concentrate } \\
\text { mixture }\end{array}$ & $\begin{array}{c}\text { Wheat } \\
\text { straw }\end{array}$ \\
\hline Dry Matter & 91.5 & 86.84 \\
Crude Protein & 13.3 & 4.56 \\
Crude Fiber & 10.1 & 35.23 \\
Fat & 4.4 & 2.48 \\
Ash & 11.8 & 16.09 \\
Nitrogen Free Extract & 51.9 & 41.64 \\
Zn/mg/kg DM & 39.5 & 10 \\
\hline
\end{tabular}

Table (2): Growth Performance of lambs fed different sources of zinc.

\begin{tabular}{|c|c|c|c|c|}
\hline \multirow{2}{*}{ Item } & \multicolumn{3}{|c|}{ Treatment } & \multirow{2}{*}{-P-value } \\
\hline & Control & Zn-So4 & Zn-Meth & \\
\hline Initial Weight & $26.5 \pm 3.27$ & $26 \pm 3.48$ & $27.3 \pm 3.1$ & 0.95 \\
\hline Final Weight & $44.75 \pm 2.39$ & $47 \pm 1.58$ & $49.2 \pm 2.56$ & 0.42 \\
\hline BW gain (kg) & $18.25 \pm 2.46$ & $21 \pm 2.67$ & $21.9 \pm 2.15$ & 0.56 \\
\hline Daily gain (g) & $99.73^{\mathrm{b}} \pm 13.45$ & $132.21^{\mathrm{a}} \pm 0.47$ & $130.96^{\mathrm{a}} \pm 4.71$ & 0.04 \\
\hline \multicolumn{5}{|c|}{ Feed intake (FI,g/day) } \\
\hline DMI of concentrate & 710 & 710 & 710 & --- \\
\hline DMI of roughage & $108.75 \pm 18.39$ & $122.75 \pm 11.01$ & $144.2 \pm 14.3$ & 0.27 \\
\hline Total DM intake & $818.75 \pm 18.39$ & $832.75 \pm 11.01$ & $854.2 \pm 14.33$ & 0.27 \\
\hline TDN Intake & $478.96^{\mathrm{b}} \pm 10.75$ & $519.05^{\mathrm{ab}} \pm 6.87$ & $547.79^{a} \pm 9.19$ & 0.01 \\
\hline SV intake & $467.50^{\mathrm{b}} \pm 0.50$ & $506.56^{\mathrm{ab}} \pm 6.70$ & $535.33^{a} \pm 9.98$ & 0.01 \\
\hline DCP Intake & $64.27^{\mathrm{b}} \pm 1.44$ & $71.70^{\mathrm{a}} \pm 0.95$ & $72.52^{\mathrm{a}} \pm 1.22$ & 0.01 \\
\hline \multicolumn{5}{|c|}{ Feed conversion ratio (g/g gain) } \\
\hline DM & $8.77 \pm 1.40$ & $6.42 \pm 0.54$ & $6.55 \pm 0.25$ & 0.13 \\
\hline TDN & $5.13 \pm 0.82$ & $4.00 \pm 0.34$ & $4.20 \pm 0.16$ & 0.23 \\
\hline SV & $5.00 \pm 0.80$ & $3.91 \pm 0.33$ & $4.11 \pm 0.15$ & 0.24 \\
\hline DCP & $1.56 \pm 0.24$ & $1.85 \pm 0.17$ & $1.81 \pm 0.07$ & 0.37 \\
\hline
\end{tabular}

Table (3): The effect of zinc source on some blood metabolites.

\begin{tabular}{lcccc}
\hline \multirow{2}{*}{ Item } & \multicolumn{3}{c}{ Treatment } & \multirow{2}{*}{ P-value } \\
\cline { 2 - 4 } & Control & Zn-So4 & Zn-Meth & \\
\hline Total Protein g/dl & $5.97 \pm 0.22$ & $5.86 \pm 0.17$ & $6.16 \pm 0.16$ & 0.48 \\
Albumin g/dl & $2.64 \pm 0.10$ & $2.62 \pm 0.06$ & $2.56 \pm 0.06$ & 0.70 \\
Globulin g/dl & $3.34 \pm 0.16$ & $3.23 \pm 0.15$ & $3.61 \pm 0.17$ & 0.24 \\
Glucose mg/dl & $52.74 \pm 1.41$ & $50.76 \pm 1.85$ & $50.75 \pm 1.97$ & 0.68 \\
Cholesterol mg/dl & $41.54^{\mathrm{b}} \pm 1.17$ & $47.64^{\mathrm{a}} \pm 1.12$ & $47.00^{\mathrm{a}} \pm 1.30$ & 0.01 \\
Triglycerides mg/dl & $26.51 \pm 1.54$ & $29.66 \pm 1.45$ & $28.99 \pm 1.22$ & 0.27 \\
Zinc $\mu \mathrm{gg} / \mathrm{ml}$ & $1.11^{\mathrm{b}} \pm 0.06$ & $1.31^{\mathrm{b}} \pm 0.06$ & $2.13^{\mathrm{a}} \pm 0.16$ & 0.01 \\
TAC mmol/L & $1.68 \pm 0.10$ & $1.73 \pm 0.20$ & $1.58 \pm 0.15$ & 0.77 \\
\hline
\end{tabular}

${ }_{a, b}$ Means of the same column in each item with different superscripts are significantly different $(P<0.05)$.

ZnSO4: Zn sulphate, $20 \mathrm{mg} / \mathrm{head} / \mathrm{day}$

Zn-Meth: Zn-methionine, $20 \mathrm{mg} / \mathrm{head} / d a y$. 
Table (4): Effect of feeding different source of Zinc to lambs on hot carcass and edible and nonedible parts.

\begin{tabular}{|c|c|c|c|c|}
\hline \multirow{2}{*}{ Items } & \multicolumn{3}{|c|}{ Treatment } & \multirow{2}{*}{ P-value } \\
\hline & Control & Zn-So4 & Zn-Meth & \\
\hline Slaughter Weight (kg) & $44.50 \pm 3.62$ & $53.33 \pm 1.86$ & $55.33 \pm 3.84$ & 0.11 \\
\hline Hot carcass $(\mathrm{kg})$ & $42.50^{\mathrm{b}} \pm 3.33$ & $50.83^{\mathrm{ab}} \pm 1.92$ & $53.67^{\mathrm{a}} \pm 3.67$ & 0.05 \\
\hline Dressing Percentage, $\%$ & $50.73 \pm 3.13$ & $52.47 \pm 1.24$ & $52.00 \pm 1.36$ & 0.42 \\
\hline Right side $(\mathrm{kg})$ & $10.47 \pm 1.31$ & $13.12 \pm 0.31$ & $13.48 \pm 0.97$ & 0.13 \\
\hline Left side $(\mathrm{kg})$ & $10.98 \pm 1.73$ & $13.33 \pm 0.30$ & $13.75 \pm 0.87$ & 0.25 \\
\hline Feet $(\mathrm{kg})$ & $1.14 \pm 0.08$ & $1.44 \pm 0.15$ & $1.37 \pm 0.02$ & 0.16 \\
\hline Head (kg) & $2.84^{\mathrm{b}} \pm 0.04$ & $3.23^{\mathrm{a}} \pm 0.14$ & $3.28^{\mathrm{a}} \pm 0.06$ & 0.03 \\
\hline Caul Fat (gm) & $186.00 \pm 5.03$ & $326.33 \pm 133.45$ & $382.40 \pm 241.54$ & 0.69 \\
\hline Tail (kg) & $2.35 \pm 0.32$ & $4.55 \pm 1.64$ & $3.90 \pm 0.70$ & 0.37 \\
\hline Kidney (gm) & $108.00 \pm 3.06$ & $108.67 \pm 4.67$ & $377.33 \pm 0.27$ & 0.43 \\
\hline Kidney Fat (gm) & $0.543 \pm 0.150$ & $0.523 \pm 0.187$ & $0.243 \pm 0.08$ & 0.33 \\
\hline Heart (gm) & $182 \pm 15.0$ & $234 \pm 17.0$ & $207 \pm 13.2$ & 0.14 \\
\hline Heart Fat (gm) & $386.67 \pm 132.83$ & $586.7 \pm 185.2$ & $553.33 \pm 104.1$ & 0.60 \\
\hline Lungs (kg) & $0.61 \pm 0.04$ & $0.67 \pm 0.05$ & $0.73 \pm 0.07$ & 0.33 \\
\hline Sex Organs, kg & $0.52 \pm 0.14$ & $0.46 \pm 0.01$ & $0.63 \pm 0.04$ & 0.40 \\
\hline Pelt (kg) & $4.69^{b} \pm 0.65$ & $4.52^{b} \pm 0.14$ & $7.30^{\mathrm{a}} \pm 0.75$ & 0.02 \\
\hline Spleen (gm) & $71.33 \pm 9.82$ & $88.00 \pm 3.46$ & $77.33 \pm 2.91$ & 0.24 \\
\hline
\end{tabular}

Table (5): Effect of feeding different source of Zinc to lambs on carcass left side and its components of lambs.

\begin{tabular}{lcccc}
\hline \multirow{2}{*}{ Item $(\mathrm{kg})$} & \multicolumn{3}{c}{ Treatment } & \multirow{2}{*}{ P-value } \\
\cline { 2 - 4 } & Control & Zn-So4 & Zn-Meth & 0.25 \\
Left Side & $10.98 \pm 1.73$ & $13.33 \pm 0.30$ & $13.75 \pm 0.87$ & 0.77 \\
Neck & $1.34 \pm 0.24$ & $1.50 \pm 0.13$ & $1.48 \pm 0.10$ & 0.21 \\
Shoulder & $2.11 \pm 0.29$ & $2.73 \pm 0.01$ & $2.66 \pm 0.29$ & 0.80 \\
1- 6 Ribs & $1.10 \pm 0.43$ & $1.24 \pm 0.17$ & $0.98 \pm 0.07$ & 0.15 \\
7 - 12 Ribs & $0.86 \pm 0.13$ & $1.11 \pm 0.08$ & $1.34 \pm 0.21$ & 0.41 \\
Rack breast & $1.17 \pm 0.27$ & $1.32 \pm 0.36$ & $1.71 \pm 0.13$ & 0.41 \\
Loin & $1.50 \pm 0.29$ & $1.21 \pm 0.02$ & $1.55 \pm 0.10$ & 0.50 \\
Legs & $3.85 \pm 0.31$ & $3.79 \pm 0.03$ & $4.19 \pm 0.28$ & 0.37 \\
Tail & $2.35 \pm 0.32$ & $4.55 \pm 1.64$ & $3.90 \pm 0.70$ & \\
\hline
\end{tabular}

ZnSO4: Zn sulphate, $20 \mathrm{mg} / \mathrm{head} / \mathrm{day}$

Zn-Meth: Zn-methionine, $20 \mathrm{mg} / \mathrm{head} / d a y$.

Table (6): Effect of feeding different source of Zinc on chemical analysis of longissimus muscle of lambs.

\begin{tabular}{lcccc}
\hline \multirow{2}{*}{ Item } & \multicolumn{3}{c}{ Treatment } & \multirow{2}{*}{ P-value } \\
\cline { 2 - 4 } & Control & Zn-So4 & Zn-Meth & 0.78 \\
Moisture & $28.73 \pm 0.61$ & $30.024 \pm 1.50$ & $28.95 \pm 0.22$ & 0.37 \\
Fat & $9.69 \pm 2.89$ & $11.23 \pm 1.55$ & $6.79 \pm 1.09$ & 0.91 \\
Ash & $3.97 \pm 0.33$ & $3.73 \pm 0.19$ & $3.93 \pm 0.39$ & 0.62 \\
Protein & $56.36 \pm 2.47$ & $58.07 \pm 2.83$ & $54.45 \pm 1.28$ & \\
\hline
\end{tabular}

ZnSO4: Zn sulphate, $20 \mathrm{mg} / \mathrm{head} /$ day

Zn-Meth: Zn-methionine, $20 \mathrm{mg} / \mathrm{head} /$ day. 